\title{
Apakah pengumuman resmi kasus pertama covid-19 oleh Presiden Joko Widodo memiliki kandungan informasi? Event study pada saham-saham LQ-45
}

\author{
1*William Wendy Ary \\ ${ }^{1}$ Institut Shanti Bhuana, Jl. Bukit Karmel No. 1 Bengkayang \\ *e-mail korespondensi: william.wendy@shantibhuana.ac.id
}

\begin{tabular}{|c|c|}
\hline Keywords & Abstract \\
\hline $\begin{array}{l}\text { event study, covid- } \\
19, \text { abnormal } \\
\text { return, indonesia } \\
\text { stock exchange, } \\
\text { LQ45 }\end{array}$ & $\begin{array}{l}\text { This study analyzes the phenomenon of the first case of Covid-19 transmission in } \\
\text { Indonesia and its impact on the capital market in Indonesia. This study aims to test } \\
\text { whether there is a negative PCAD pattern after the first announcement of the covid- } \\
19 \text { virus transmission case on the Indonesian capital market and to prove that the } \\
\text { Indonesian capital market experienced a significant decline in returns after the first } \\
\text { announcement period of the covid-19 virus transmission. Stocks that are included as } \\
\text { LQ45 stocks are being utilized and event study is the method to analyze the market } \\
\text { response during the window period ( } t-10, t+10) \text { and uses the independent sample }- \\
\text { test to compare the average abnormal return. mean (AAR) and mean cumulative } \\
\text { abnormal return (CAAR). The results of this study indicate that the market takes a } \\
\text { wait \& see strategy, PCAD shows the form of a negative sign after the event and } \\
\text { there is a difference between AAR and CAAR } 10 \text {-days before and } 10 \text {-days after the } \\
\text { event. Overall, this research shows that the market has responded negatively to } \\
\text { information related to the Covid-19 virus. }\end{array}$ \\
\hline
\end{tabular}

\begin{tabular}{|c|c|}
\hline Kata Kunci & Abstrak \\
\hline $\begin{array}{l}\text { event study, covid- } \\
19, \text { abnormal } \\
\text { return, bursa efek } \\
\text { Indonesia, LQ45 }\end{array}$ & $\begin{array}{l}\text { Studi ini menganalisis fenomena kasus pertama penularan Covid-19 di Indonesia } \\
\text { dan dampaknya terhadap pasar modal di Indonesia. Penelitian ini bertujuan untuk } \\
\text { menguji ada tidaknya pola PCAD negatif setelah pengumuman pertama kasus } \\
\text { penularan virus Covid-19 di pasar modal Indonesia dan untuk membuktikan bahwa } \\
\text { pasar modal Indonesia mengalami penurunan imbal hasil yang signifikan setelah } \\
\text { periode pengumuman pertama kali terjadinya penularan virus covid-19. Data } \\
\text { penelitian ini menggunakan saham yang termasuk dalam indeks LQ45 dan } \\
\text { menggunakan metode event study untuk menganalisis respon pasar selama periode } \\
\text { window (t-10, t }+10 \text { ). Selain itu, menggunakan independent sample t-test untuk } \\
\text { membandingkan rata-rata abnormal return. rata-rata return abnormal saham (AAR) } \\
\text { dan rata-rata return kumulatif return abnormal (CAAR). Hasil penelitian ini } \\
\text { menunjukkan bahwa pasar mengambil strategi wait \& see, PCAD menunjukkan } \\
\text { bentuk tanda negatif setelah peristiwa, serta terdapat perbedaan antara AAR dan } \\
\text { CAAR } 10 \text { hari sebelum dan } 10 \text { hari setelah peristiwa. Secara keseluruhan, penelitian } \\
\text { ini menunjukkan bahwa pasar merespons secara negatif informasi terkait virus } \\
\text { Covid-19. }\end{array}$ \\
\hline
\end{tabular}




\section{PENDAHULUAN}

Perekonomian dunia pada beberapa tahun terakhir mengalami goncangan yang sangat hebat dalam beberapa tahun belakangan ini. Dua isu perekonomian yang sampai saat ini menyebabkannya goncangan hebat tersebut adalah isu perang dagang antara Republik Rakyat Tiongkok dan Amerika Serikat dan isu wabah virus corona atau lebih familiar disebut dengan pandemi covid-19 (corona virus disease 2019). Diantara kedua isu tersebut yang sampai saat ini memberikan dampak terbesar dan masif adalah efek dari pandemi Covid-19.

Pandemi covid-19 memberikan dampak yang besar dalam aspek sosio-ekonomi masyarakat seperti kemiskinan, pendidikan, perlindungan sosial, pendapatan dan lapangan kerja, remitansi, perdagangan global, harga komoditas, keamanan pangan, dan pariwisata UNDP (2020). Kasus penularan virus covid-19 pertama kali diperkirakan terjadi pada tanggal 8 Desember 2019 di kota Wuhan, Republik Rakyat Tiongkok. Kluster pertama kasus penularan virus ini tedeteksi pada tanggal 31 Desember 2019 dan menjangkiti sekitar 41 orang (World Health Organization, 2020). Selanjutnya, hingga tanggal 3 Mei 2021 tercatat penularan virus sudah mencapai skala global yang mana telah menjangkiti sekitar 152.534.452 orang di 223 negara dan 3.198.528 orang diantara telah meninggal dunia (World Health Organization, 2020)

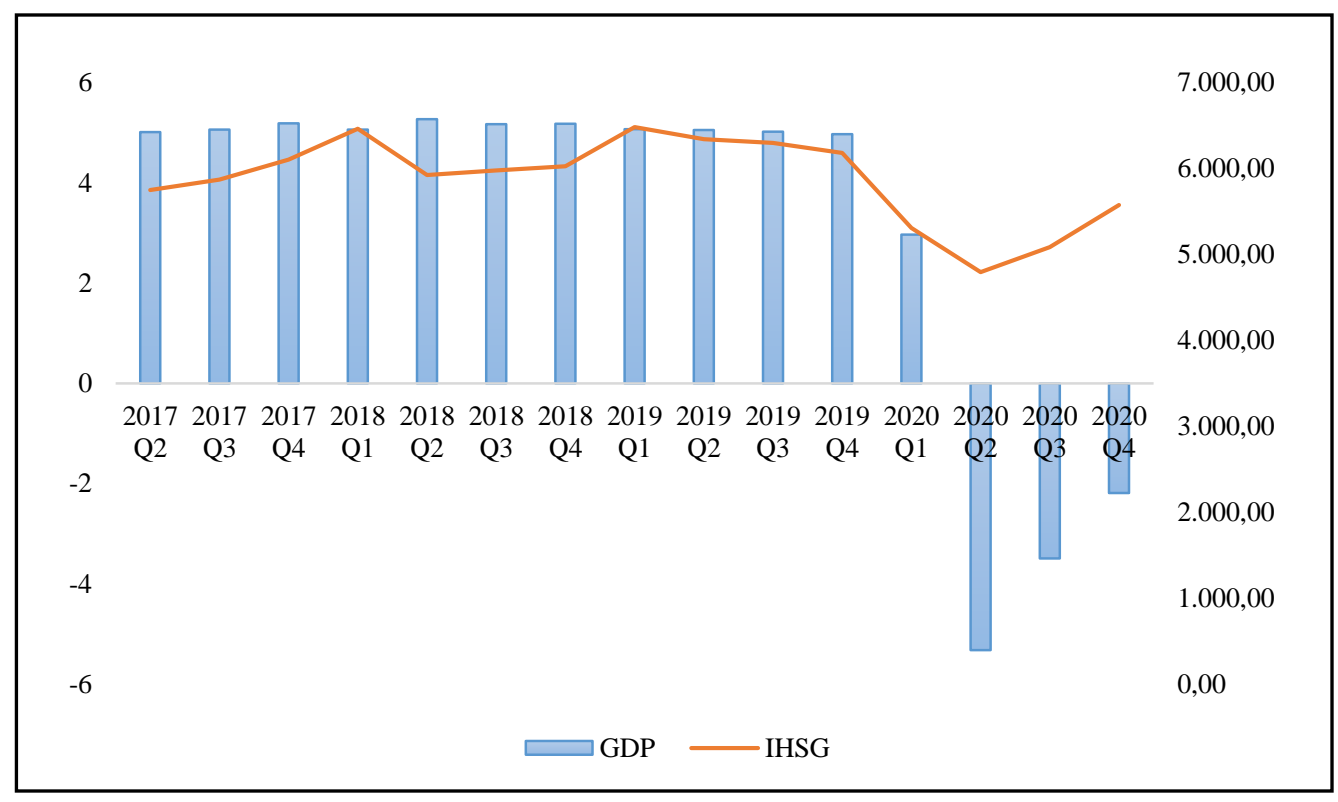

Gambar 1. Pertumbuhan PDB (\%) dan IHSG (Rp) periode 2017 Q2 - 2020 Q4

Republik Indonesia mencatat kasus penularan penularan pertama covid-19 pada tanggal 2 Maret 2020 yang diumumkan langsung oleh Presiden Joko Widodo dimana penularan dari virus terjadi pada dua Warga Negara Indonesia dari Warga Negara Jepang (CNN Indonesia, 2020). Penularan virus ini telah memberikan dampak negatif hampir di segala aspek dan segi kehidupan masyarakat yang ada di Indonesia. Produk Domestik Bruto (PDB) merupakan salah satu faktor makro ekonomi yang dapat digunakan sebagai pengukur 


\section{Entrepreneurship Bisnis Manajemen Akuntansi (E-BISMA), 2(1), 27-39 \\ William Wendy Ary}

pertumbuhan ekonomi sebuah negara. Informasi yang terkandung di dalam data PDB dapat mempengaruhi fluktuasi Indeks Saham Komposit (Funashima, Iizuka, \& Ohtsuka, 2020). Sejak kuartal 1 hingga kuartal 4 tahun 2020, PDB dan IHSG Republik Indonesia mengalami penurunan yang sangat signifikan (lihat Gambar 1) dan penyebab utama yang paling mempengaruhi penurunan ini disebabkan oleh pandemi Covid-19.

Salah satu isu yang sering ditelaah oleh para akademisi pasar modal ketika berhadapan dengan fenomena krisis global adalah isu mengenai efisiensi pasar modal. Jin (2016) meneliti efisiensi pasar modal beberapa negara maju di Asia dan menemukan bahwa krisis ekonomi tahun 2008 secara negatif mempengaruhi efisiensi pasar secara negatif. Rizvi \& Arshad (2016) juga semakin mempertegaskan bahwa selama krisis terutama pada negaranegara Asia Tenggara seperti Malaysia, Singapura, dan Indonesia sangat mempengaruhi efisiensi pasar modalnya. Dua penelitian yang dilakukan oleh Jin (2016) dan Rizvi \& Arshad (2016) merupakan sedikit dari beberapa penelitian lainnya yang menguji fenomena krisis ekonomi global pada tahun 2008.

Pandemi Covid-19 merupakan fenomena krisis ekonomi global dan sampai saat ini sudah banyak sekali penelitian-penelitian yang muncul untuk menelaah pengaruhnya pada berbagai aspek baik dari aspek kesehatan hingga sosio ekonomi masyarakat. Namun, masih sedikit penelitian yang mencoba untuk menguji bagaimana peristiwa-peristiwa yang terjadi sejak kasus pertama kali dikonfirmasikannya kluster penularan sampai penyebarannya dapat mempengaruhi efisiensi pasar modal di sebuah negara. Penelitian ini bertujuan untuk menguji efisiensi pasar modal Indonesia selama periode awal Covid-19 dengan menggunakan pendekatan pengujian pasar bentuk setengah kuat dan mengambil peristiwa pengumuman pertama kluster penularan pertama yang diumumkan pada tanggal 2 Maret 2020 oleh Presiden Joko Widodo di Indonesia. Selain itu, penelitian ini juga menguji kandungan informasi selama periode jendela 10 (sepuluh) hari pra pengumuman dan 10 (sepuluh) hari pasca pengumuman kluster penularan Covid-19 di Indonesia. Struktur penulisan dari paper ini adalah sebagai berikut. Bagian kedua dari paper ini menjabarkan teori-teori yang digunakan dan memunculkan hipotesis-hipotesis yang diuji dalam paper ini. Bagian ketiga dari paper ini akan membahas metode penelitian yang digunakan untuk menganalisis isu dalam penelitian. Bagian keempat akan menjabarkan hasil analisis dan membahas hasil temuan secara komprehensif. Bagian lima akan memaparkan kesimpulan akhir dan memberikan beberapa rekomendasi dari hasil penelitian. Bagian keenam memaparkan daftar referensi yang digunakan untuk meneliti isu penelitian.

\section{KAJIAN TEORI DAN HIPOTESIS}

Penelitian yang terkait dengan pengujian efisiensi pasar modal pada umumnya menggunakan tiga pendekatan dari teori hipotesis pasar efisien (efficient market hypothesis). Teori ini dikemukakan pertama kalinya oleh Fama (1970) dan teori ini pada dasarnya menekankan bahwa ada hubungan yang erat tantara harga saham dan informasi yang ada baik yang bersifat privat atau publik. Selain itu, teori ini membagi efisiensi pasar modal kedalam tiga bentuk yaitu 1) pasar efisien bentuk lemah, 2) pasar efisien bentuk setengah kuat, dan 3) pasar efisien bentuk kuat. Pertama, pasar efisien dalam bentuk lemah dapat 
terjadi apabila harga-harga dari sekuritas dapat dijelaskan secara penuh oleh informasiinformasi yang ada di mas lalu. Kedua, pasar efisien dalam bentuk setengah kuat terbentuk apabila harga-harga sekuritas secara penuh dapat dijelaskan oleh semua informasi yang terpublikasikan termasuk salah satunya adalah informasi yang berkaitan dengan laporanlaporan keuangan yang dipublikasikan oleh emiten-emiten. Ketiga, pasar efisien dalam bentuk kuat dapat terbentuk apabila harga-harga sekuritas secara penuh mencerminkan semua informasi yang tersedia termasuk informasi yang privat. Maka dari itu, pengujian efisiensi pasar modal pada dasarnya adalah untuk menguji relevansi antara harga saham dengan informasi yang ada dengan tujuan untuk mengetahui apakah informasi tersebut mencerminkan harga saham pada periode tertentu.

Meskipun sudah banyak penelitian yang menganalisis efisiensi pasar modal di beberapa negara, masih sedikit penelitian yang mencoba untuk meneliti dari perspektif pasar modal di Indonesia dan ini menjadi alasan penting untuk menganalisis efisiensi pasar modal Indonesia dengan harapan dapat memberikan sebuah konfirmasi apakah pasar modal di Indonesia selama masa pandemi merupakan pasar yang efisien atau tidak. Andrianto \& Mirza (2016) mencoba menguji efisiensi pasar modal Indonesia dengan menggunakan pendekatan pasar efisien bentuk lemah dan hasil analisnya menyebutkan bahwa pasar modal Indonesia memang efisien. Selanjutnya, Setianto \& Manap (2011) menyebutkan bahwa pasar modal Indonesia merupakan pasar yang efisien dan sejalan dengan teori efficient market hypothesis. Dapat disimpulkan bahwa dalam beberapa tahun belakangan, pasar modal Indonesia adalah pasar modal yang efisien. Namun, perlu dicatat bahwa beberapa penelitian tersebut belum mengakomodasi super event yang berpotensi menyebabkan gejolak yang ada di pasar modal dan belum menguji potensi gejolak tersebut terhadap efisiensi pasar modal Indonesia.

Isu mengenai efisiensi pasar modal juga terkait dengan bentuk respon pasar selama periode jendela (window periods). Pengujian pada periode jendela sangat penting untuk dapat melihat bagaimana pasar secara agregat bereaksi terhadap peristiwa tertentu dan biasanya menguji apakah terdapat post-earning announcement drift (PEAD) selama periode jendela yang dijadikan cut-off pengamatan. Börjesson \& Johansson (2012) meneliti PEAD perbankan dari tahun 2005-2009 dan menemukan bahwa ada perbedaan yang sangat jelas pada perbankan yang mampu menyikapi krisis ekonomi dengan baik dibandingkan dengan yang tidak. Dalam penelitian kali ini, peneliti mencoba menggunakan terminologi postcovid announcement drift (PCAD) sebagai adaptasi dari PEAD karena menggunakan isu krisis global covid-19 sebagai fokus pembahasan utama. Sojka (2018) menguji fenomena PEAD di pasar modal polandia dengan menggunakan metode milik Bernard \& Jacob K. Thomas (1989) dan temuan mereka konsisten dengan beberapa penelitian terdahulu yaitu nilai abnormal return tertinggi diperoleh saat 10 hari setelah pengumuman yang berkaitan dengan pendapatan perusahaan dan dalam 14 hari sebelum pengumuman selanjutnya dilaporkan. Berdasarkan beberapa penelitian terdahulu tersebut, maka saya mengajukan hipotesis pertama dalam penelitian ini yaitu:

Hipotesis 1: Adanya pola PCAD yang negatif setelah pengumuman pertama kasus penularan virus covid-19 pada pasar modal Indonesia. 
Selain itu, pandemi Covid-19 merupakan sebuah fenomena yang menyebabkan kejutan (shock) di pasar keuangan dan dampak yang dihasilkan dari fenomena ini bersifat masif dan bahkan berdampak pada hampir seluruh sektor industri di seluruh dunia. Berdasarkan penelitian terkini yang dilakukan oleh Naidu \& Ranjeeni (2021) dalam papernya menyebutkan bahwa pandemi Covid-19 telah secara nyata mempengaruhi secara negatif persentase return pada 12 sektor industri yang ada di Australia dan metode yang digunakan oleh mereka adalah studi peristiwa (event study). He, Sun, Zhang, \& Li (2020) juga meneliti terkait dampak pandemi Covid-19 terhadap beberapa sektor industri di Republik Rakyat Tiongkok dan menemukan bahwa Covid-19 berdampak negatif pada sektor transportasi, pertambangan, elektronik, dan lingkungan. Berdasarkan, beberapa hasil analisis dari penelitian-penelitian tersebut, maka saya mengajukan hipotesis kedua dalam penelitian ini yaitu:

Hipotesis 2: Pasar modal Indonesia mengalami penurunan return yang signifikan setelah periode pengumuman pertama kasus penularan virus Covid-19 $(t+1, t+10)$ dibandingkan sebelum periode pengumuman pertama kasus penularan virus covid-19 (t-1, t-10).

\section{METODE PENELITIAN}

Penelitian ini merupakan jenis penelitian kuantitatif dan menggunakan data perdagangan harian saham-saham yang termasuk kedalam kategori saham indeks LQ45. Periode analisis dilakukan dari tanggal 9 Desember 2019 sampai 17 Maret 2020 yang diklasifikasikan kedalam 3 periode pengamatan yaitu 1) periode estimasi dari tanggal 9 Desember 2019 sampai 14 Februari 2020 yaitu selama 46 hari, 2) periode jendela dari tanggal 17 Februari 2020 sampai 16 Maret 2020 yaitu selama 21 hari. Periode jendela ini dibagi lagi menjadi tiga bagian yaitu 1) periode sebelum peristiwa dari tanggal 17 Februari 2020 sampai 28 Februari 2020 yaitu selama 10 hari, 2) periode peristiwa yang dimulai pada tanggal 2 Maret 2020 dimana Presiden Jokowi secara langsung mengumumkan kasus pertama penularan virus covid-19, dan 3) periode setelah peristiwa dari tanggal 3 Maret 2020 sampai 16 Maret 2020 (lihat Gambar 2).

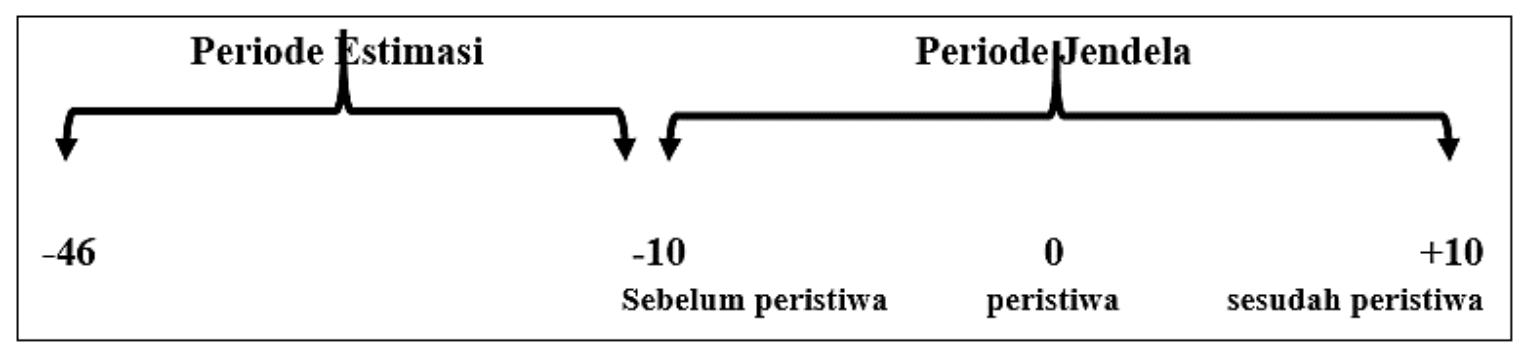

Gambar 2. Periode Pengamatan

Supaya analisis studi peristiwa dapat terhindar dari potensi peristiwa-peristiwa lainnya yang dapat mengganggu dan dapat menjelaskan dampak covid-19 secara utuh, maka periode estimasi pada penelitian ini menggunakan titik cut-off hari ketika kasus pertama penularan Covid-19 terjadi di Wuhan yang secara resmi dipublikasikan oleh WHO yaitu pada tanggal 8 Desember 2019 namun karena pada tanggal tersebut perdagangan bursa sedang libur dan 
baru dimulai pada hari selanjutnya, maka tanggal pertama pada periode estimasi dimulai pada tanggal 9 Desember 2019.

Penelitian ini menggunakan dua prosedur yang masing-masing digunakan untuk menguji hipotesis pertama dan kedua. Untuk prosedur pertama, peneliti menggunakan pendekatan pengujian pasar efisien bentuk setengah kuat (event study). Adapun tahapantahapan proses untuk melakukan prosedur pengujian hipotesis pertama adalah sebagai berikut:

1) Mengidentifikasi bentuk, efek, dan waktu peristiwa

2) Menentukan rentang waktu studi peristiwa dari periode estimasi sampai periode jendela

3) Menentukan metode penyesuaian return yang digunakan untuk menghitung abnormal return. Peneliti menggunakan market model sebagai metode untuk menghitung abnormal return. Berikut adalah formula dari market model:

$$
E\left(R_{i t}\right)=\alpha_{i}+\beta_{i} R M_{t}+\varepsilon_{i t}
$$

dimana:

$E\left(R_{i t}\right)=$ return harapan (expected return)

$\alpha_{i} \quad=$ konstanta emiten $\mathrm{i}$

$\beta_{i} \quad=$ koefisen beta emiten $\mathrm{i}$

$R M_{t} \quad=$ return pasar periode $\mathrm{t}$

$\varepsilon_{i t} \quad=$ error term emiten i pada periode $\mathrm{t}$

4) Menghitung abnormal return disekitar periode peristiwa. Pada tahapan ini, peneliti mengurangi nilai return aktual emiten i pada periode t terhadap nilai return harapan yang dihasilkan dari kalkulasi menggunakan market model dan nilai yang dihasilkan dari pengurangan inilah yang lazim disebut dengan nilai abnormal return.

5) Menghitung rata-rata abnormal return (average abnormal return) dan rata-rata return kumulatif (cumulative abnormal return). Berikut adalah formula menghitung masingmasing return.

a. $A A R_{t}=\frac{\sum_{i=0}^{n} A R_{t}}{k}$

dimana:

$A A R_{t}=$ abnormal return rata-rata pada periode $\mathrm{t}$

$k \quad=$ jumlah emiten yang dianalisis

b. $C A R_{t}=\sum_{t=-n}^{t=+n} A R_{t}$

dimana:

$C A R_{t}=$ abnormal return kumulatif rata-rata pada periode $\mathrm{t}$

$k \quad=$ jumlah emiten yang dianalisis

6) Menghitung apakah return tak normal rata-rata atau return tak normal kumulatif yang sudah dihitung pada langkah 5 sejalan dengan hipotesis pertama. Pengujian ini menggunakan uji t sebagai acuan untuk menguji hipotesis. Untuk mendapatkan koefisien t-hitung, maka peneliti terlebih dahulu melakukan pembagian antara nilai rata-rata abnormal return terhadap koefisien standar kesalahan estimasi dari nilai rata-rata 
abnormal return untuk mendapatkan nilai rata-rata abnormal return standarisasi. Berikut adalah formulasinya:

$$
A A R_{t} S=\frac{A A R_{t}}{K S E\left(A A R_{t}\right)}
$$

Selanjutnya, setelah memperoleh nilai rata-rata abnormal return standarisasi, maka untuk mendapatkan koefisien t-hitung, peneliti membagi jumlah rata-rata abnormal return standarsasi terhadap akar kuadrat jumlah emiten yang menjadi sampel penelitian. Berikut adalah formulasinya:

$$
t_{\text {hitung }}=\frac{\sum A A R_{t} S}{\sqrt{k}}
$$

Selanjutnya, untuk prosedur kedua, peneliti menggunakan metode yang lazim pada umumnya digunakan yaitu dengan membandingkan abnormal return dan cumulative abnormal return saat sebelum dan sesudah peristiwa pengumuman penularan virus Covid19 oleh Presiden Joko Widodo. Alat analisis yang digunakan untuk membandingkan abnormal return dan cumulative abnormal return adalah menggunakan uji parametrik independent sample t-test. Uji independent sample t-test dapat digunakan apabila data - data yang digunakan terdistribusi secara normal dan apabila data - data tersebut tidak terdistribusi secara normal maka alat analisis adalah dengan menggunakan analisis data nonparametrik seperti uji mann-whitney.

\section{HASIL DAN PEMBAHASAN}

\section{Analisis Deskriptif}

Analisis deskriptif dilakukan untuk menjabarkan karakteristik data penelitian secara agregat. Analisis deskriptif penelitian ini dapat dilihat pada tabel 1 berikut:

Tabel 1

Statistik Deskriptif

\begin{tabular}{cccccc}
\hline Variabel & N & Minimum & Maksimum & Rata-Rata & Simpangan Baku \\
\hline AAR & 21 & -0.0151 & 0.0118 & -0.0015 & 0.0069 \\
CAAR & 21 & -0.0323 & 0.0198 & 0.0061 & 0.0153 \\
\hline
\end{tabular}

Sumber: data diolah, 2021

Berdasarkan hasil statistik deskriptif yang tertera pada tabel 1, maka secara garis kita dapat menyimpulkan bahwa selama periode jendela rata-rata abnormal return saham-saham yang tergabung kedalam saham LQ45 menghasilkan return terendah sebesar $-1,51 \%$ (0.0151), return tertinggi sebesar $1,18 \%$ (0.0118), nilai rata-rata sebesar $-0,15 \%(-0.0015)$, dan nilai simpangan baku sebesar $0.69 \%$ (0.0069). Selanjutnya, selama periode jendela ratarata kumulatif abnormal return saham-saham yang tergabung kedalam saham LQ45 menghasilkan return terendah sebesar $-3,23 \%$ (0.0323), return tertinggi sebesar $1,98 \%$ (0.0198), nilai rata-rata sebesar $0,61 \%(0.0061)$, dan nilai simpangan baku sebesar $1.53 \%$ (0.0153). 


\section{Entrepreneurship Bisnis Manajemen Akuntansi (E-BISMA), 2(1), 27-39 \\ William Wendy Ary}

\section{Pengujian Hipotesis}

a. Adanya pola PCAD yang negatif setelah pengumuman pertama kasus penularan virus covid-19 pada pasar modal Indonesia (Hipotesis 1)

Pada tahapan ini peneliti melaksanakan prosedur seperti yang tertera pada bagian metode penelitian dan hasil pengujian tersebut dapat dilihat pada Tabel 2:

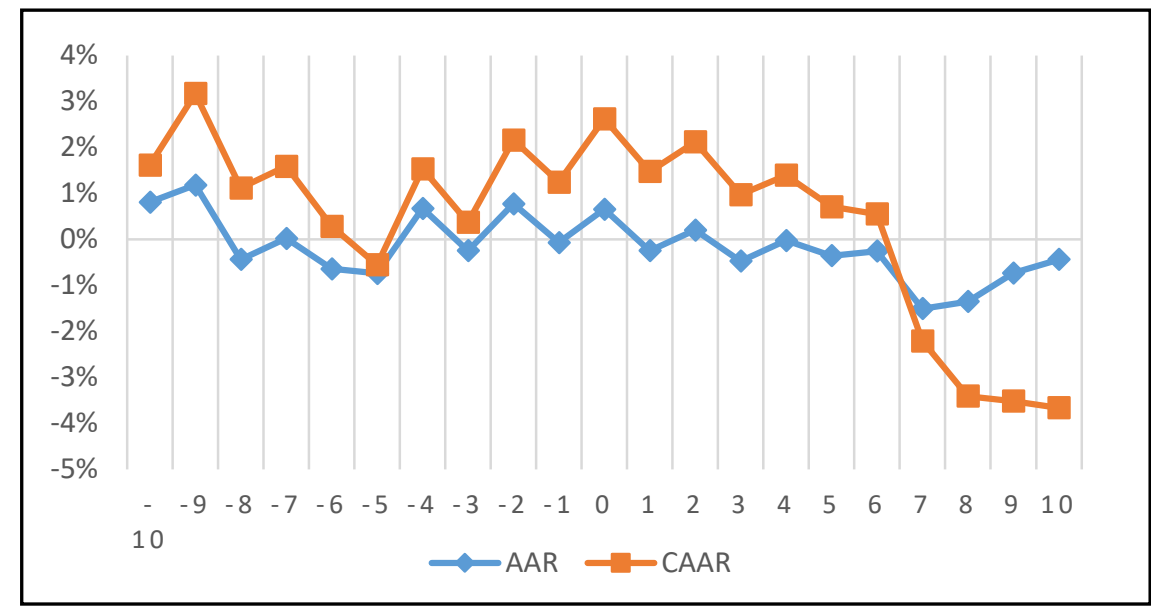

Sumber: data diolah, 2021

Gambar 3

Pola Pergerakan Rata-Rata Abnormal Return (AAR) dan Rata-Rata Abnormal Return Kumulatif (CAAR)

Pada panel A yang tersaji pada Tabel 2 kita dapat melihat sebaran respon pasar pada periode jendela peristiwa pengumuman penularan virus Covid-19 di Indonesia yang mana pasar merespon dengan sangat cepat bahkan sebelum pengumuman disampaikan secara publik. Pasar merespon dengan sangat cepat pada periode t-10, t-9, t-8, t-6, t-5, t-4, dan t-2. Walaupun pasar bereaksi dengan cepat selama periode - periode ini, namun responnya masih relatif normal karena koefisien return selama periode pengamatan masih menunjukkan tingkat return yang bervariasi dan tidak terjadi secara berkepanjangan. Lebih jauh lagi, menariknya pada periode t0 (periode peristiwa) ternyata pasar merespon positif peristiwa pengumuman penularan covid-19 di Indonesia dan temuan ini tentu saja cukup mengejutkan karena pada awalnya peneliti menduga respon pasar seharusnya menunjukkan respon yang negatif. Peneliti menduga ada dua penjelasan logis yang mungkin dapat menjelaskan temuan ini yaitu 1) pasar masih optimis bahwa pengumuman kasus penularan virus Covid-19 ini belum memberikan dampak yang signifikan terhadap industri dan perekonomian di Indonesia atau 2) pasar memang terlambat merespon kasus penularan virus ini karena pasar masih mengambil posisi wait \& see untuk melihat situasi perekonomian dalam beberapa hari kedepan. Untuk mengkonfirmasi dugaan ini, peneliti menggunakan telaah yang lebih komprehensif lagi dengan menggunakan metode yang digunakan oleh Naidu \& Ranjeeni (2021) terutama menggunakan indikator rata-rata abnormal return kumulatif (lihat Panel B pada Tabel 2). Setelah melaksanakan metode tersebut, peneliti menemukan bahwa selama periode - periode sekitar peristiwa pasar (t-1, t-10; t-1, t0; t0, t1) memang menggunakan strategi wait \& see karena nilai koefisien selama periode tersebut 
masih positif dan pergerakan rata-rata return kumulatif pun masih membentuk pola yang stasioner.

Tabel 2

Rata-Rata Abnormal Return (AAR) dan

Rata-Rata Abnormal Return Kumulatif (CAAR)

\begin{tabular}{|c|c|c|c|c|}
\hline \multicolumn{5}{|c|}{ A. Rata-Rata Abnormal Return (AAR) } \\
\hline Periode & Jumlah Emiten & Hasil & SD & t-hitung \\
\hline-10 & 45 & $0.8073 \%$ & 0.0186 & $2.9169 * * *$ \\
\hline-9 & 45 & $1.1808 \%$ & 0.0229 & $4.2665 * * *$ \\
\hline-8 & 45 & $-0.4366 \%$ & 0.0149 & $-1.5776^{*}$ \\
\hline-7 & 45 & $0.0187 \%$ & 0.0159 & 0.0677 \\
\hline-6 & 45 & $-0.6435 \%$ & 0.0180 & $-2.3250 * * *$ \\
\hline-5 & 45 & $-0.7404 \%$ & 0.0184 & $-2.6752 * * *$ \\
\hline-4 & 45 & $0.6740 \%$ & 0.0178 & $2.4351 * *$ \\
\hline-3 & 45 & $-0.2468 \%$ & 0.0193 & -0.8916 \\
\hline-2 & 45 & $0.7719 \%$ & 0.0241 & $2.7888 * * *$ \\
\hline-1 & 45 & $-0.0721 \%$ & 0.0289 & -0.2603 \\
\hline 0 & 45 & $0.6528 \%$ & 0.0275 & $2.3585^{* *}$ \\
\hline+1 & 45 & $-0.2463 \%$ & 0.0308 & -0.8897 \\
\hline+2 & 45 & $0.1994 \%$ & 0.0249 & 0.7203 \\
\hline+3 & 45 & $-0.4729 \%$ & 0.0190 & $-1.7086^{* *}$ \\
\hline+4 & 45 & $-0.0261 \%$ & 0.0209 & -0.0942 \\
\hline+5 & 45 & $-0.3567 \%$ & 0.0280 & -1.2887 \\
\hline+6 & 45 & $-0.2562 \%$ & 0.0282 & -0.9258 \\
\hline+7 & 45 & $-1.5078 \%$ & 0.0294 & $-5.4480 * * *$ \\
\hline+8 & 45 & $-1.3534 \%$ & 0.0331 & $-4.8901 * * *$ \\
\hline+9 & 45 & $-0.7327 \%$ & 0.0504 & $-2.6474 * * *$ \\
\hline+10 & 45 & $-0.4390 \%$ & 0.0202 & $-1.5861 *$ \\
\hline
\end{tabular}

B. Rata-Rata Abnormal Return Kumulatif (CAAR)

\begin{tabular}{cccc}
\hline Periode & Hasil & SD & t-hitung \\
\hline$-10,+10$ & $-3.2257 \%$ & 0.0153 & $-11.6546^{* * *}$ \\
$-10,-2$ & $1.3854 \%$ & 0.0056 & $4.0610^{* * *}$ \\
$-5,-2$ & $0.4586 \%$ & 0.0050 & $2.0636^{* *}$ \\
$-1,+1$ & $4.9993 \%$ & 0.0033 & $21.0480^{* * *}$ \\
$-1,0$ & $0.5807 \%$ & 0.0017 & $2.1669^{* *}$ \\
$0,+1$ & $0.4065 \%$ & 0.0017 & $1.4782^{*}$ \\
$+1,+2$ & $-0.0469 \%$ & 0.0014 & -0.1762 \\
$+1,+3$ & $-0.5198 \%$ & 0.0024 & $-1.8084^{* *}$ \\
$+1,+4$ & $-0.5459 \%$ & 0.0024 & $-1.5199^{*}$ \\
$+1,+5$ & $-0.9025 \%$ & 0.0033 & $-2.0935^{* *}$ \\
$+1,+6$ & $-1.1588 \%$ & 0.0041 & $-2.8235^{* * *}$ \\
$+1,+7$ & $-2.6666 \%$ & 0.0088 & $-5.8059^{* * *}$ \\
$+1,+8$ & $-4.0200 \%$ & 0.0138 & $-10.8086^{* * *}$ \\
$+1,+9$ & $-4.7528 \%$ & 0.0174 & $-16.7673^{* * *}$ \\
$+1,+10$ & $-5.1918 \%$ & 0.0198 & $-16.6608^{* * *}$ \\
\hline
\end{tabular}

Sumber: data diolah, 2021

Keterangan: Uji t dalam tahapan ini menggunakan pendekatan milik Brown \& Warner (1985). Koefisien t-hitung mengacu pada tabel student- $t$ untuk ukuran sampel sebanyak 45 sampel yang masing-masing sebesar 1,3006 untuk $* \mathrm{p}<10 \%, 1,6794$ untuk **p<5\%, dan 2,4121 untuk ***p $<1 \%$. 
Selanjutnya, peneliti juga menemukan bahwa beberapa hari setelah peristiwa pasar juga masih memberikan reaksi yang panjang terutama pada periode $t+3, t+7, t+8, t+9$, dan $\mathrm{t}+10$ pada panel a tabel 2. Pada titik ini juga peneliti menemukan pada periode - periode tersebut return yang dihasilkan juga menunjukkan tanda negatif yang mana ini mengindikasikan bahwa pasar merespon negatif kasus penularan pertama covid-19. Lebih jauh lagi, peneliti mencoba melihat pola earnings drift (lihat panel b tabel 2) selama sepuluh hari setelah peristiwa penularan ini dan hasilnya pun konsisten dengan yang dihasilkan pada panel a yang mana mayoritas menunjukkan tanda negatif dari $t-3$ sampai $t+10$. Temuan ini mengindikasikan bahwa pasar memberikan respon yang negatif terhadap pandemi virus covid-19 di Indonesia dan tentu saja penelitian ini konsisten dengan beberapa penelitian sebelumnya. Maka dari itu, secara garis besar, hipotesis pertama penelitian ini terdukung.

b. Pasar modal Indonesia mengalami penurunan return yang signifikan setelah periode pengumuman pertama kasus penularan virus covid-19 $(\mathrm{t}+1, \mathrm{t}+10)$ dibandingkan sebelum periode pengumuman pertama kasus penularan virus covid-19 (t-1, t-10).

Selain menguji respon pasar terhadap peristiwa kasus penularan pertama covid-19 di Indonesia, peneliti mencoba untuk menguji perbedaan kinerja rata-rata abnormal return (AAR) dan kinerja rata-rata abnormal return kumulatif (CAAR). Alat analisis yang digunakan adalah independent sample t-test yang dioperasikan di dalam perangkat lunak SPSS 24. Sebelum melakukan perbandingan, peneliti terlebih dahulu melakukan pengujian normalitas distribusi data dengan menggunakan uji One-Sample Kolmogorov-Smirnov dan hasil pengujiannya dapat dilihat pada tabel 3 berikut:

Tabel 3

Uji One-Sample Kolmogorov-Smirnov

\begin{tabular}{cccc}
\hline Variabel & $\mathrm{N}$ & Z Value & Sig. \\
\hline AAR & 20 & 0,583 & 0,886 \\
CAAR & 20 & 1,125 & 0,159 \\
\hline Sumber: data diolah, 2021 & & &
\end{tabular}

Sumber: data diolah, 2021

Berdasarkan hasil yang tersaji pada tabel 3, maka dapat disimpulkan bahwa data penelitian ini terdistribusi normal karena nilai signifikansi diatas 5\% $(0,05)$ sehingga hipotesis nul diterima dan uji beda dapat menggunakan uji parametrik yaitu independent sample t-test. Hasil uji independent sample t-test dapat dilihat pada tabel 4 berikut 
Entrepreneurship Bisnis Manajemen Akuntansi (E-BISMA), 2(1), 27-39

William Wendy Ary

Tabel 4

Uji Independent Sample T-Test

\begin{tabular}{ccccc}
\hline Variabel & $\mathrm{N}$ & Rata-Rata & t-stastistik & Sig. \\
\hline AAR_Sebelum & 10 & 0,0013 & \multirow{2}{*}{2,367} & $0,029 * *$ \\
AAR_Sesudah & 10 & $-0,0052$ & & \\
CAAR_Sebelum & 10 & 0,0211 & \multirow{2}{*}{3,084} & $0,006 * * *$ \\
CAAR_Sesudah & 10 & $-0,0004$ & & \\
\hline
\end{tabular}

Sumber: data diolah, 2021

Koefisien t-hitung mengacu pada tabel student- $t$ untuk ukuran sampel sebanyak 45 sampel yang masing-masing sebesar 1,3006 untuk *p<10\%, 1,6794 untuk **p<5\%, dan 2,4121 untuk ***p<1\%.

Berdasarkan hasil yang tersaji pada tabel 4, maka ada perbedaan yang sangat signifikan saat sebelum dan sesudah pengumuman kasus pertama penularan covid-19 di Indonesia dimana 10 hari sebelum peristiwa terjadi memiliki rata-rata kinerja return masih positif dibandingkan 10 hari sesudah peristiwa memiliki rata-rata kinerja return yang negatif dan temuan ini konsisten pada dua variabel rata-rata abnormal return (AAR) dan rata-rata abnormal return kumulatif (CAAR). Temuan ini tentu saja kembali mengkonfirmasi bahwa peristiwa Covid-19 berdampak negatif terhadap pasar modal Indonesia dan mendukung hipotesis kedua dalam penelitian ini.

\section{KESIMPULAN DAN SARAN}

Pandemi Covid-19 memberikan dampak yang besar dalam aspek sosio-ekonomi masyarakat seperti kemiskinan, pendidikan, perlindungan sosial, pendapatan dan lapangan kerja, remitansi, perdagangan global, harga komoditas, keamanan pangan, dan pariwisata (UNDP, 2020). Pandemi Covid-19 merupakan fenomena krisis ekonomi global dan sampai saat ini sudah banyak sekali penelitian-penelitian yang muncul untuk menelaah pengaruhnya pada berbagai aspek baik dari aspek kesehatan hingga sosio ekonomi masyarakat. Namun, masih sedikit penelitian yang mencoba untuk menguji bagaimana peristiwa-peristiwa yang terjadi sejak kasus pertama kali dikonfirmasikannya kluster penularan sampai penyebarannya dapat mempengaruhi efisiensi pasar modal di sebuah negara. Meskipun sudah banyak penelitian yang menganalisis efisiensi pasar modal di beberapa negara, masih sedikit penelitian yang mencoba untuk meneliti dari perspektif pasar modal di Indonesia dan ini menjadi alasan penting untuk menganalisis efisiensi pasar modal Indonesia dengan harapan dapat memberikan sebuah konfirmasi apakah pasar modal di Indonesia selama masa pandemi merupakan pasar yang efisien atau tidak.

Penelitian ini merupakan jenis penelitian kuantitatif dan menggunakan data perdagangan harian saham-saham yang termasuk kedalam kategori saham indeks LQ45. Periode analisis dilakukan dari tanggal 9 Desember 2019 sampai 17 Maret 2020. Penelitian ini menggunakan dua prosedur yang masing-masing digunakan untuk menguji hipotesis pertama dan kedua. Untuk prosedur pertama, peneliti menggunakan pendekatan pengujian pasar efisien bentuk setengah kuat (event study). untuk prosedur kedua, peneliti menggunakan metode yang lazim pada umumnya digunakan yaitu dengan membandingkan abnormal return dan cumulative abnormal return saat sebelum dan sesudah peristiwa pengumuman penularan virus covid-19 oleh Presiden Joko Widodo. Alat analisis yang 
digunakan untuk membandingkan abnormal return dan cumulative abnormal return adalah menggunakan uji parametrik independent sample t-test. Pasar merespon dengan sangat cepat pada periode $\mathrm{t}-10, \mathrm{t}-9, \mathrm{t}-8, \mathrm{t}-6, \mathrm{t}-5, \mathrm{t}-4$, dan $\mathrm{t}-2$. Walaupun pasar bereaksi dengan cepat selama periode - periode ini, namun responnya masih relatif normal karena koefisien return selama periode pengamatan masih menunjukkan tingkat return yang bervariasi dan tidak terjadi secara berkepanjangan

Setelah melaksanakan metode tersebut, peneliti menemukan bahwa selama periode periode sekitar peristiwa pasar ( $\mathrm{t}-1, \mathrm{t}-10 ; \mathrm{t}-1, \mathrm{t} 0 ; \mathrm{t} 0, \mathrm{t}-1)$ memang menggunakan strategi wait \& see karena nilai koefisien selama periode tersebut masih positif dan pergerakan rata-rata return kumulatif pun masih membentuk pola yang stasioner. Berdasarkan hasil yang tersaji pada tabel 4, maka ada perbedaan yang sangat signifikan saat sebelum dan sesudah pengumuman kasus pertama penularan Covid-19 di Indonesia dimana 10 hari sebelum peristiwa terjadi memiliki rata-rata kinerja return masih positif dibandingkan 10 hari sesudah peristiwa memiliki rata-rata kinerja return yang negatif dan temuan ini konsisten pada dua variabel rata-rata abnormal return (AAR) dan rata-rata abnormal return kumulatif (CAAR). Penelitian memiliki beberapa kelemahan seperti ukuran sampel yang kecil, periode pengamatan yang relatif pendek, serta jumlah peristiwa penting yang digunakan hanya satu saja sehingga tidak bisa melihat dampak pandemi Covid-19 secara keseluruhan. Penelitian selanjutnya diharapkan dapat mengisi beberapa kelemahan dari penelitian ini dengan menambah periode pengamatan yang lebih panjang, menambah pembahasan dengan menambah peristiwa-peristiwa lainnya, serta dapat meneliti dampak covid-19 terhadap pasar modal apabila menggunakan paradigma industri - industri yang ada di Indonesia.

\section{DAFTAR PUSTAKA}

Andrianto, Y., \& Mirza, A. R. (2016). A Testing of Efficient Markets Hypothesis in Indonesia Stock Market. Procedia - Social and Behavioral Sciences, 219, 99-103.

Bernard, V. L., \& Jacob K. Thomas. (1989). Discussion of Post-Earnings-Announcement Drift: Delayed Price Response or Risk Premium? Journal of Accounting Research, 27, $1-35$.

Börjesson, M., \& Johansson, E. (2012). Risk and Uncertainty in the Banking Sector. University of Gothenburg.

CNN Indonesia. (2020). Jokowi Umumkan Dua WNI Positif Corona di Indonesia. Tersedia di https://www.cnnindonesia.com/nasional/20200302111534-20-479660/jokowiumumkan-dua-wni-positif-corona-di-indonesia. Diakses pada April 2021.

Fama, E. F. (1970). Session Topic: Stock Market Price Behavior Session Chairman: Burton G. Malkiel Efficient Capital Markets: A Review Of Theory And Empirical Work. The Journal of Finance, 25(2), 383-417.

Funashima, Y., Iizuka, N., \& Ohtsuka, Y. (2020). GDP announcements and stock prices. Journal of Economics and Business, 108, 105872.

He, P., Sun, Y., Zhang, Y., \& Li, T. (2020). COVID-19's Impact on Stock Prices Across Different Sectors-An Event Study Based on the Chinese Stock Market. Emerging Markets Finance and Trade, 56(10), 2198-2212. 
Jin, X. (2016). The impact of 2008 financial crisis on the efficiency and contagion of Asian stock markets: A Hurst exponent approach. Finance Research Letters, 17, 167-175.

Naidu, D., \& Ranjeeni, K. (2021). Effect of coronavirus fear on the performance of Australian stock returns: Evidence from an event study. Pacific-Basin Finance Journal, 66, 101520.

Rizvi, S. A. R., \& Arshad, S. (2016). How does crisis affect efficiency? An empirical study of East Asian markets. Borsa Istanbul Review, 16(1), 1-8.

Setianto, R. H., \& Manap, T. A. A. (2011). The behavior of Indonesian stock market: Structural breaks and nonlinearity. Gadjah Mada International Journal of Business, 13(3), 209-226.

Sojka, M. (2018). Post Earnings Announcement Drift (PEAD) in Polish Stock Market. SSRN Electronic Journal. 3202541.

UNDP. (2020). Covid-19 Socio-Economic Impact. Tersedia di https://www.undp.org/coronavirus/socio-economic-impact-covid-19. Diakses pada April 2021.

World Health Organization. (2020). Emergencies preparedness, response Novel Coronavirus - China. Tersedia di https://www.who.int/emergencies/disease-outbreaknews/item/2020-DON233. Diakses pada April 2021. 